\title{
Hubungan Channel Youtube Sam Kolder terhadap Minat Membuat Vidio Travelling
}

\author{
Mochamad Ismail Sabilillah *, Anne Maryani \\ Prodi Manajemen Komunikasi, Fakultas Ilmu Komunikasi, Universitas Islam \\ Bandung, Indonesia. \\ *ismailsabilillah@gmail.com, anne.maryani@unisba.ac.id
}

\begin{abstract}
Based on technological developments and along its development human communication media will continue to develop. One example of the development of communication media is the emergence of new media such as the internet and social media. Social media has various types such as microblog, sharing media, online journals and others. The most commonly used social media in Indonesia is YouTube social media. Youtube is a type of social media sharing type, because it facilitates its users to share in the form of videos. One of the content creators on YouTube is Sam Kolder, he is a filmmaker, videographer, and photographer from the travel company Beautiful Destination. Sam has a distinctive character from the making of a traveling video uploaded on his YouTube channel that made the attention of videography activists especially those in Indonesia such as members of the Editorest.Id group.This study seeks to explain the relationship of the Kold youtube channel owned by Sam Kolder to the interest in making a traveling video to members of the Editorest.Id group. in this study viewed in terms of the use of social media consisting of context, communication, collaboration, and connections that exist on the Kold channel. The theory used is the theory of S-R YouTube channel Sam Kolder is a variable $(\mathrm{X})$ which means that the stimulus and interest in making videos traveling is a variable $(\mathrm{Y})$, namely the response. A quantitative method with a correlational approach was used in this study to examine the relationship between the two variables. The results showed that (1) Kold's youtube channel has a very strong relationship with the interest in making a traveling video (2) context has a strong relationship with the interest in making a traveling video (3) communication has a strong relationship with the interest in making a traveling video (4) collaboration have a strong enough relationship with an interest in making a traveling video (5) connection has a strong enough relationship with an interest in making a traveling video.
\end{abstract}

Keywords: Social Media, Youtube, Interest, S-R Theory.

\begin{abstract}
Abstrak. Berdasarkan perkembangan teknologi dan seiring perkembangannya manusia media komunikasi akan terus berkembang. Salah satu contoh perkembangan media komunikasi adalah munculnya media baru seperti internet dan media sosial. Media sosial memiliki beragam jenis seperti microblog, media berbagi, jurnal online dan lainnya. Media sosial yang paling sering digunakan di Indonesia ada media sosial youtube. Youtube merupakan salah satu media sosial berjenis media berbagi, karena memfasilitasi penggunanya untuk berbagidalam bentuk vidio. Salah satu content creator yang ada di youtube adalah Sam Kolder, ia adalah seorang filmmaker, videographer, dan photographer dari perusahaan travel Beautiful Destination. Sam memiliki karakter tersendiri dari pembuatan sebuah vidio travelling yang di unggah di channel youtubenya yang membuat mendapat perhatian dari para penggiat videography terutama yang ada di Indonesia seperti anggota grup Editorest.Id.Penelitian ini berusaha untuk menjelaskan hubungan dari channel youtube Kold yang dimiliki oleh Sam Kolder terhadap minat membuat vidio travelling pada anggota grup Editorest.Id. dalam penelitian ini dilihat dari segi penggunaan media sosial yang terdiri dari context, communication, collaboration, dan connection yang ada pada channel Kold. Teori yang digunakan adalah teori $\mathrm{S}-\mathrm{R}$ channel youtube Sam Kolder merupakan variabel $(\mathrm{X})$ yang berarti stimulus dan minat pembuatan vidio travelling merupakan variabel (Y) yaitu respon. Metode kuantitatif dengan pendekatan korelasional digunakan dalam penelitian ini untuk menguji ada tidaknya hubungan antara kedua variabel. Hasil penelitian menunjukan bahwa (1) channel youtube Kold memiliki hubungan yang sangat kuat dengan minat membuat vidio travelling (2) context memiliki hubungan yang kuat dengan minat membuat vidio travelling (3) communication memiliki hubungan yang kuat dengan minat membuat vidio travelling (4) collaboration memiliki hubungan yang cukup kuat dengan minat membuat vidio travelling (5) connection memiliki hubungan yang cukup kuat dengan minat membuat vidio travelling.
\end{abstract}

Kata Kunci: Media Sosial, Youtube, Minat. Teori S-R. 


\section{A. Pendahuluan}

Berdasarkan perkembangan tekhnologi dan seiring perkembangan manusia, media komunikasi akan terus berkembang dimulai dari zaman dahulu dimana media komunikasi dengan menggunakan batu, bahasa isyarat, tulisan, media cetak, lalu berkembang dengan teknologi dibidang audio visual seperti radio dan televisi, hingga munculnya media baru (new media) seperti internet dan media sosial yang menggantikan media konvensional atau media lama (old media).

Media sosial adalah salah satu bentuk dari berkembangnya teknologi komunikasi bermedia. Media sosial merupakan salah satu platform yang muncul di media baru. Dari laporan berjudul "Essential Insight into internet, social media, mobile, and E-Commerce Use Around The World" yang diterbitkan pada Januari 2018, dari total populasi Indonesia sebanyak 265,4 juta jiwa, pengguna aktif media sosialnya mencapai 130 juta dengan presentasi 49 persen. Dari bergam jenis media sosial yang aktif digunakan oleh masyarakat Indonesia Youtube menduduki peringkat pertama dengan presentase $43 \%$, yang menduduki kedua terbanyak adalah Facebook dengan presentase $41 \%$. Youtube merupakan salah satu media sosial yang berjenis media sharing, karena Youtube memfasilitasi penggunanya untuk berbagi media dalam bentuk vidio Content creator adalah kegiatan menyebarkan informasi yang ditansformasikan kedalam sebuah gambar, vidio, dan tulisan atau disebut sebagai sebuah konten, yang kemudian konten tersebut disebarkan melalui platform.

Sam Kolder adalah salah satu content creator youtube yang memiliki banyak subscribers atau pengikutnya. Sam Kolder adalah seorang filmmaker, editor, dan photographer dari perusahaan travel Beautiful Destination. Sam Kolder terkenal karena hasil vidio yang di buat dirinya mempunyai karakter dan ciri khas yang sangat bagus, maka dari itu channel Sam yang bernama "KOLD" memiliki 791.311 subcribers. Hasil dari vidio travelling yang dibuat oleh Sam sangatlah bagus dengan gaya editing yang dimilikinya hingga dapat menginspirasi subscribernya atau orang-orang yang menonton vidionya tersebut terutama para penggiat videograpy seperti komunitas Editorest. Id.

Berdasarkan latar belakang yang telah diuraikan, perumusan masalah dalam penelitian ini sebagai berikut: "Adakah Hubungan Antara Channel Youtube Sam Kolder terhadap Minat membuat Vidio Travelling ?". Selanjutnya, tujuan dalam penelitianini dapat diuraikan dalam pokok-pokok sebagai berikut:

1. Untuk mengetahui hubungan antara Context di dalamm channel youtube Kold terhadap minat membuat vidio travelling anggota komunitas Editorest.Id.

2. Untuk mengetahui hubungan antara Communication di dalam channel youtube Kold terhadap minat membuat vidio travelling anggota komunitas Editorest.Id.

3. Untuk mengetahui ada hubungan antara Collaboration di dalam channel youtube Kold terhadap minat membuat vidio travelling anggota komunitas Editorest.Id.

4. Untuk mengetahui ada hubungan antara Connection di dalam channel youtube Kold terhadap minat membuat vidio travelling anggota komunitas Editorest.Id

\section{B. Landasan Teori}

\section{Teori Stimulus Respon (S-R)}

Model Stimulus respons (S - R) adalah model komunikasi paling dasar. Model ini dipengaruhi oleh disiplin psikologi, khususnya yang beraliran behavioristic. Model tersebut menggambarkan hubungan stimulus - respons. Menurut (Effendy, 2001:132) teori stimulus respon berasal dari psikologi. Objek material dari psikologi dan komunikasi adalah sama, yaitu manusia yang jiwanya meliputi komponen-komponen sikap, opini, perilaku, kognisi, afeksi, dan konasi. Teori stimulus respon (S-R) mendasarkan asumsi yang mana perubahan perilaku terjadi tergantung kepada kualitas rangsangan (stimulus) yang berkomunikasi dengan organisme. Artinya, suatu keadaan internal pada individu dapat menghasilkan perilaku tertentu yang disebut dengan respons, perilaku tersebut timbul akibat adanya stimulus. 
Gambar 2.1 Model S-R

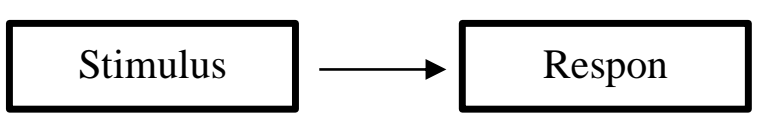

Pada penelitian ini, peneliti menggunakan teori stimulus-respon (S-R). Teori stimulusrespon ( $\mathrm{S}-\mathrm{R})$ mendasarkan asumsi yang mana perubahan perilaku terjadi tergantung kepada kualitas rangsangan (stimulus) yang berkomunikasi dengan organisme. Stimulus pada penelitian ini adalah channel youtube Sam Kolderyang kemudian akan menimbulkan respon dari penonton yaitu minat membuat vidio travelling.

\section{Minat}

Menurut Sumadi Suryabrata (2002:68) definisi minat adalah "Suatu rasa lebih suka dan rasa ketertarikan pada suatu hal atau aktivitas tanpa ada yang menyuruh". Minat pada dasarnya adalah penerimaan akan suatu hubungan antara diri sendiri dengan sesuatu hal diluar dirin ya. Semakin kuat atau dekat hubungan tersebut semakin besar minatnya. Minat dapat diartikan sebagai "Kecenderungan yang tinggi terhadap sesuatu, tertarik, perhatian, gairah dan keinginan". Pendapat lain tentang pengertian minat yaitu yang diungkapkan oleh T. Albertus yang diterjemahkan Sardiman A.M, minat adalah "Kesadaran seseorang bahwa suatu obyek, seseorang, suatu soal maupun situasi yang mengandung sangkut paut dengan dirinya" (2006:32).

Minat pada seseorang akan suatu obyek atau hal tertentu tidak akan muncul dengan sendirinya secara tiba-tiba dalam diri individu. Minat dapat timbul pada diri seseorang melalui proses. Dengan adanya perhatian dan interaksi dengan lingkungan maka minat tersebut dapat berkembang. Banyak faktor yang mempengaruhi minat seseorang akan hal tertentu. Menurut Crow and Crow yang dikutip (Dimyati Mahmud,2001:56) yang menyebutkan bahwa ada tiga faktor yang mendasari timbulnya minat seseorang yaitu :

1. Faktor dorongan yang berasal dari dalam. Kebutuhan ini dapat berupa kebutuhan yang berhubungan dengan jasmani dan kejiwaan.

2. Faktor motif sosial. Timbulnya minat dari seseorang dapat didorong dari motif sosial yaitu kebutuhan untuk mendapatkan penghargaan dan lingkungan dimana mereka berada.

3. Faktor emosional. Faktor ini merupakan ukuran intensitas seseorang dalam menaruh perhatian terhadap sesuatu kegiatan atau obyek tertentu.

Dengan demkian dapat disimpulkan bahawa minat dapat muncul karena beberapa faktor diantaranya adalah faktor dari luar dan dari dalam.

\section{Hasil Penelitian dan Pembahasan}

Hubungan channel youtube Sam Kolder $(X)$ dengan minat membuat video travelling $(\mathbf{Y})$

Berikut adalah penelitian mengenai hubungan antara channel youtube Sam Kolder dengan kesadaran merek, yang diuji menggunakan teknik analisis korelasi Rank Spearman. Hasil pengujian dijelaskan pada tabel 1 .

Tabel 3.1 Hasil Pengujian

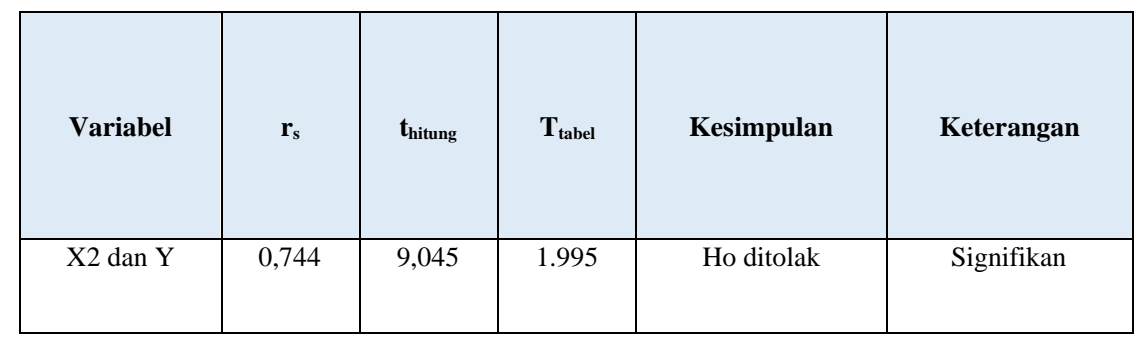

Berdasarkan table diatas dapat dilihat bahwa koefisien korelasi Rank Spearman (Rs) 
adalah sebesar 0,814. Kemudian hasil uji signifikasi diperoleh dari nilai thitung sebesar 11,384 dan nilai ttabel adalah sebesar 1,995. Maka dapat dilihat bahwa thitung $(11,384)>$ ttabel $(1,995)$ sehingga menyatakan bahwa H0 ditolak. Selain itu jika dilihat dari nilai intrepetasi nilai $\mathrm{r}$, koefisien korelasi sebesar 0,814 berada diantara 0,80 - 1,000 yang menunjukan bahwa ada hubungan yang sangat kuat diantara kedua variabel tersebut. Sehingga berdasarkan tabel diatas disimpulkan bahwa terdapat hubungan yang kuat antara channel youtube Kold dengan minat membuat video travelling.

\section{Hubungan antara dimensi context (X1) dengan minat membuat video travelling (Y)}

Tabel 3.2 Hasil Pengujian

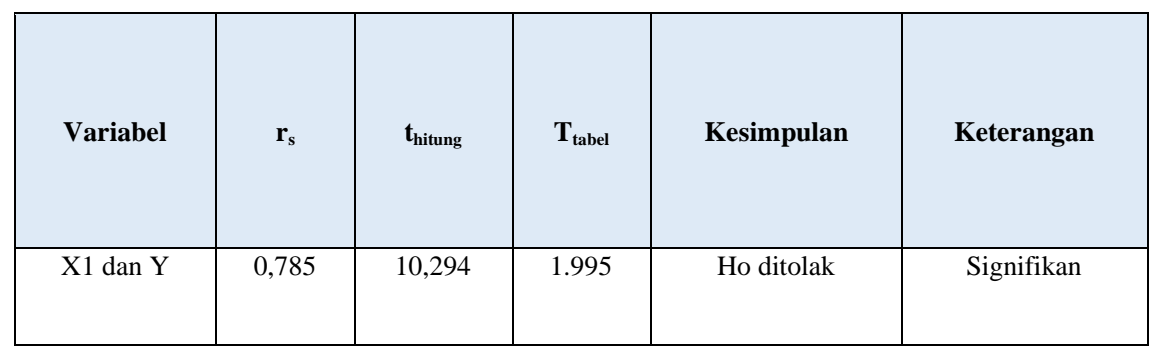

Berdasarkan table diatas dapat dilihat bahwa koefisien korelasi Rank Spearman (Rs) adalah sebesar 0,785. Kemudian hasil uji signifikasi diperoleh dari nilai thitung sebesar 10,294 dan nilai ttabel adalah sebesar 1,995. Maka dapat dilihat bahwa thitung $(10,294)>\operatorname{ttabel}(1,995)$ sehingga menyatakan bahwa H0 ditolak. Selain itu jika dilihat dari nilai intrepetasi nilai $\mathrm{r}$, koefisien korelasi sebesar 0,785 berada diantara 0,60 - 0,799 yang menunjukan bahwa ada hubungan yang kuat diantara kedua variabel tersebut. Sehingga berdasarkan tabel diatas disimpulkan bahwa terdapat hubungan yang kuat antara dimensi context dengan minat membuat video travelling.

Hubungan antara dimensi communication (X2) dengan minat membuat video travelling (Y)

Tabel 3.3 Hasil Pengujian

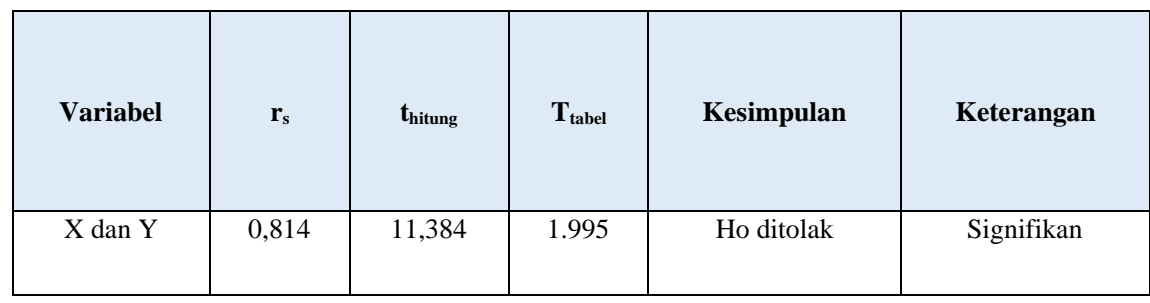

Berdasarkan tabel diatas dapat dilihat bahwa koefisien korelasi Rank Spearman (Rs) adalah sebesar 0,744. Kemudian hasil uji signifikasi diperoleh dari nilai thitung sebesar 10,294 dan nilai ttabel adalah sebesar 1,995. Maka dapat dilihat bahwa thitung $(9,045)>$ ttabel $(1,995)$ sehingga menyatakan bahwa H0 ditolak. Selain itu jika dilihat dari nilai intrepetasi nilai $\mathrm{r}$, koefisien korelasi sebesar 0,744 berada diantara 0,60 - 0,799 yang menunjukan bahwa ada hubungan yang kuat diantara kedua variabel tersebut. Sehingga berdasarkan tabel diatas disimpulkan bahwa terdapat hubungan yang kuat antara dimensi communication dengan minat membuat video travelling. 


\section{Hubungan antara dimensi collaboration (X3) dengan minat membuat video travelling (Y)}

Tabel 3.4 Hasil Pengujian

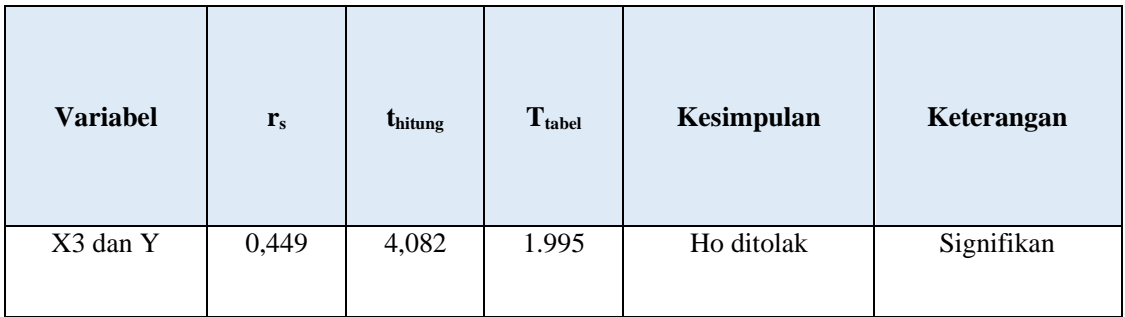

Berdasarkan tabel diatas dapat dilihat bahwa koefisien korelasi Rank Spearman (Rs) adalah sebesar 0,449. Kemudian hasil uji signifikasi diperoleh dari nilai thitung sebesar 4,082 dan nilai ttabel adalah sebesar 1,995. Maka dapat dilihat bahwa thitung $(4,082)>$ ttabel $(1,995)$ sehingga menyatakan bahwa H0 ditolak. Selain itu jika dilihat dari nilai intrepetasi nilai r, koefisien korelasi sebesar 0,449 berada diantara 0,40 - 0,599 yang menunjukan bahwa ada hubungan yang cukup kuat diantara kedua variabel tersebut. Sehingga berdasarkan tabel diatas disimpulkan bahwa terdapat hubungan yang kuat antara dimensi collaboration dengan minat membuat video travelling.

Hubungan antara dimensi connection (X4) dengan minat membuat video travelling (Y)

Tabel 3.5 Hasil Pengujian

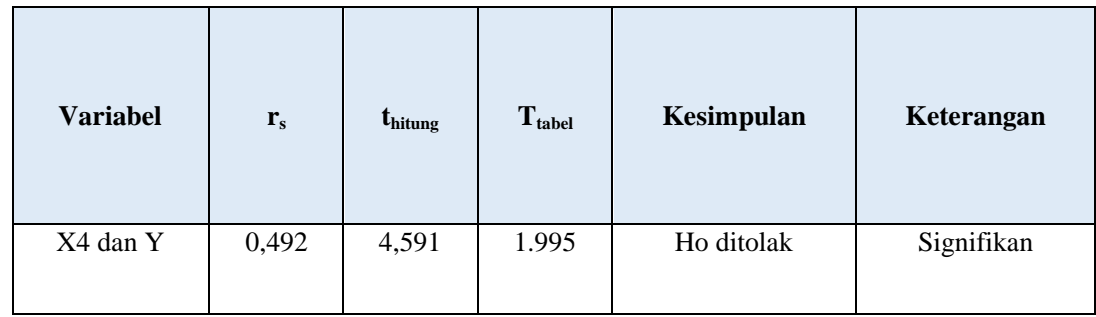

Berdasarkan tabel diatas dapat dilihat bahwa koefisien korelasi Rank Spearman (Rs) adalah sebesar 0,492. Kemudian hasil uji signifikasi diperoleh dari nilai thitung sebesar 4,591 dan nilai ttabel adalah sebesar 1,995. Maka dapat dilihat bahwa thitung $(4,591)>$ ttabel $(1,995)$ sehingga menyatakan bahwa HO ditolak. Selain itu jika dilihat dari nilai intrepetasi nilai r, koefisien korelasi sebesar 0,492 berada diantara 0,40 - 0,599 yang menunjukan bahwa ada hubungan yang cukup kuat diantara kedua variabel tersebut. Sehingga berdasarkan tabel diatas disimpulkan bahwa terdapat hubungan yang kuat antara dimensi connection dengan minat membuat video travelling.

\section{Kesimpulan}

Berdasarkan pembahasan dalam penelitian ini, peneliti menyimpulkan beberapa hasil penelitian sebagai berikut:

1. Dari hasil penelitian ini, dapat dilihat bahwa variabel dimensi context pada channel youtube Kold memiliki peran dalam minat membuat vidio travelling pada anggota grup Editorest.Id. Besar koefisien korelasi antara dimensi context dan minat membuat vidio travelling adalah 0,785 yang nenunjukan terdapat tingkat hubungan yang kuat diantara keduanya.

2. Dari hasil penelitian ini, dapat dilihat bahwa variabel dimensi communication pada channel youtube Kold memiliki peran dalam minat membuat vidio travelling pada anggota grup Editorest.Id. Besar koefisien korelasi antara dimensi communication dan minat membuat vidio travelling adalah 0,744 yang nenunjukan terdapat tingkat 
hubungan yang kuat diantara keduanya.

3. Dari hasil penelitian ini, dapat dilihat bahwa variabel dimensi collaboration pada channel youtube Kold memiliki peran dalam minat membuat vidio travelling pada anggota grup Editorest.Id. Besar koefisien korelasi antara dimensi collaboration dan minat membuat vidio travelling adalah 0,449 yang nenunjukan terdapat tingkat hubungan yang cukup kuat diantara keduanya.

4. Dari hasil penelitian ini, dapat dilihat bahwa variabel dimensi connection pada channel youtube Kold memiliki peran dalam minat membuat vidio travelling pada anggota grup Editorest.Id. Besar koefisien korelasi antara dimensi connection dan minat membuat vidio travelling adalah 0,492 yang nenunjukan terdapat tingkat hubungan yang cukup kuat diantara keduanya.

\section{E. Saran}

\section{Saran Teoritis}

1. Peneliti selanjutnya dapat mengembangkan penelitian dengan menambah variabel di luar variabel yang digunakan di penelitian ini.

2. Disarankan untuk penelitian selanjutnya untuk memperdalam bahasan dan menemukan referensi buku mengenai konsep dan dimensi yang digunakan di penelitian ini.

\section{Saran Praktis}

1. Peneliti menyarankan kepada para penggiat videography untuk menjadi pengguna channel youtube Kold, karena di dalamnya banyak sekali referensi dan pengetahuan dalam pembuatan vidio travelling.

2. Peneliti menyarankan untuk memilih informasi yang ada di media sosial terutama youtube, karena sebuah channel youtube dapat menimbulkan perubahan perilaku.

\section{Daftar Pustaka}

[1] Abrar, Ana Nadya. 2003. Teknologi Komunikasi: Perspektif Ilmu Komunikasi.Yogyakarta: LESFI

[2] Ahmadi, Abu.2009. Psikologi Umum. Jakarta : Rineka cipta.

[3] Arikunto, Suharsimi. 2006. Prosedur Penelitian Suatu Pendekatan Praktek. Jakarta: Rineka Cipta.

[4] Budiargo, Dian. 2015. Berkomunikasi Ala Net Generation. Jakarta: PT.Elex Media Komputindo.

[5] Effendy, Onong Uchjana.2001. Ilmu Komunikasi Teori dan Praktek. Bandung : PT.Remaja Rosdakarya.

[6] Nasrullah, Rulli. 2015 .Media Sosial : Perspektif Komunikasi, Budaya dan Sosioteknologi. Bandung: Simbiosa Rekatama Media.

[7] Sugiyono, 2008. Metode Penelitian Kuantitatif Kualitatif dan R\&D. Bandung : Alfabeta. 